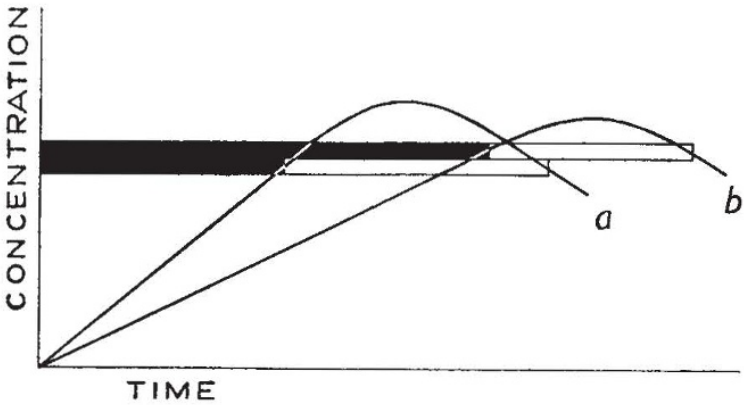

AVERAGE WIDTH OF THE BLACK AND WHITE BARS IN THE FEMALE (above) AND MALE (below) ANTERIOR BREAST FEATHERS OF BARRED PLYMOUTH ROCKS. HY POTHETICAL CURVES OF THE CONCENTRATION OF THE PIGMENT-INHIBITING SUBSTANCE IN THE MALE (a) AND FEMALE $(b)$ FEATHER GERMS AND THEIR THRESHOLD VALUES ARE ADJUSTED TO FIT THE ACTUAL WIDTH OF BARS

growth between homologous flights of a cock and a hen with very marked sexual dimorphism of the pattern ${ }^{3}$. Fluctuations in growth-rates of feathers of the same tract certainly do occur in different individuals, and possibly a small consistent sexual difference also exists. Unfortunately, I have not been able, for a long time, to work with chickens and therefore I have not been able to collect sufficient data relating to this point. In any event, from published and some unpublished data I also find that the differences in growth-rate between male and female breast feathers are not sufficiently high to account for the differences of pattern. In fact, one can calculate, starting from the male pattern, the growth-rate expected in order to account for the width of the female double bar. Pooling together the figures for three cocks and two hens, the average growth-rate of the hen's anterior breast feather should be, in order to agree with the width of pattern, $2 \cdot 022 \pm 0.0265 \mathrm{~mm}$. per day, while it is actually $1.865 \pm 0.0243$; in the hen's posterior breast feather it should be $2 \cdot 340 \pm 0 \cdot 0258$, while it is in fact $2 \cdot 160+0.0381$. The differences between the expected and observed figures are : $0 \cdot 157 \pm 0 \cdot 0359$ and $0 \cdot 180 \pm 0 \cdot 0460$, that is, they are significant. Therefore, I think that a difference in rate of growth, even if statistically ascertained, could not explain the different width of the double bar, to say nothing of the fact that the higher the rate of growth, the greater should be the proportion of white to black ${ }^{3}$, which is just the contrary of what occurs.

The larger proportion of white in the male feather is easy to understand on the above assumption. As has often been pointed out, the genetical and physiological evidence is quite convincing that the $B$ factor acts as a rhythmic suppressor of pigmentation : the positive effect, in barring, is inhibition of pigmentation, and Nickerson's hypothesis is in line with this view. Thus a higher dose of $B$ gene ( $B B$ genotype in male) would presumably form a greater amount of the inhibiting substance, which would interrupt pigment formation for a longer time (about $1 \cdot 3$ to 1 is the male to female white bar ratio, absolute width, in the breast feather) than the $B O$ female genotype.

It is more difficult to see why the width of the double bar should be larger in the hemizygous sex. Supposing that a threshold of a concentration of the inhibiting substance must be reached for the melanophores to react, and that the rate of formation of the substance is in some way proportional to the dose of $B$ gene present; in the $B O$ genotype the melanophores may work for a longer time (about 1.84 to 1 is the female to male black ratio, according to Agostini's average data) in forming pigment, before the inhibiting substance reaches the threshold concentration (hence the greater width of black bars). Once it is reached, the elimination of the substance should take place more rapidly (because of its lower total concentration), hence the absolute narrowness of the white bar. Since the black bar alone is, on the average, 1.84 times wider in male than in female breast feather, even a relatively short duration of the 'white' phase will bring about a greater width of the total bar in the female. The process might be represented in a diagrammatic way as in the accompanying illustration, where the relative width of black and white bars in male and female feathers are taken from the mean values of Agostini's data, while the curves of concentration of the inhibiting substance are, of course, entirely hypothetical and roughly adjusted to fit the actual morphological data.

${ }^{1}$ Nickerson, M., J. Exp. Zool., 95, 361 (1944).

${ }^{2}$ Henke, K., Zool. Anz. Suppl., 8, 176 (1935); Biol. Zentrbl., 59, 459 (1939)

s Montalenti, G., J. Exper. Zool., 69, 269 (1934).

- Montalenti, (G., Atti V Congr. Mond. Pollicolt., Roma, 1933, 2, 397 (1934); Ras8. Clin. Terap. e Sci. affini, 23, 1 (1934).

6 Agostini, A., Arch. Zool. Ital, 26, 319 (1939). Montalenti, G, PIoc. VII Int. Genet. Congr., 1939, 205 (1941).

'Danforth, C. H., and Foster, F., J. Exp. Zool., 48, 443 (1929).

\section{BIOLOGICAL INVESTIGATIONS IN THE AEGEAN SEA}

\section{By Prof. ENRICO TORTONESE}

\section{Zoological Institute and Museum, University of Turin}

$\mathrm{A}$ $\mathrm{S}$ is well known, the eastern Mediterranean has been far less biologically explored than the western. It was therefore a very welcome occasion to spend several months (1943) in the Island of Rhodes (Aegean Sea) and carry out there a series of researches, the main result of which has been to add a number of species to those previously found and recorded. Knowledge of Aegean animals was first improved by E. Forbes about a century ago. In 1926 a group of Italian zoologists investigated the shores of Rhodes and neighbouring islands; other scattered data are to be found in various scientific papers, such as those concerning the famous Thor expedition. New and careful investigations are desirable for both an exact understanding of geographical distribution, variations and migrations of Mediterranean species and for ascertaining the spreading of those which have immigrated from the Red Sea through the Suez Canal : it is certain that some of them have reached the Aegean Sea, following the main current along the coasts of Syria and Asia Minor.

Of such zoological groups as Porifera, Cnidaria, Echinodermata, Nemertea, Tunicata and fishes no collections had hitherto been made in Rhodes and nothing is actually known. The marine fauna does not seem to be a very rich one; both species and individuals appear relatively scarce and it is improbable that this may be due to lack of proper researches. Steepness of submarine soil and frequent roughness of sea, consequent on almost continuous and violent winds, are probably responsible for this scantiness 
of life. General physiognomy, however typically Mediterranean, differs somewhat from that of the western shores of this Sea, as well as from that of its more northern parts; a number of species, for example, fishes, are peculiar to warm waters. Field work (hindered by war conditions) on various types of sea-bottom and sea-shore has revealed some noteworthy biocænosis. The predominance of Carddita sulcata, a lamellibranchiate molluscan, along the sandy beaches was already known; a peculiar association of Asterina and Chiton under the stones was now noted on rocky bottom in the harbour, with plenty of seaweeds; various other invertebrates were sharing the same habitat. Calcareous sponges, seaanemones (Anemonia sulcata), two species of Nemerteans, free and sedentary Polychæta, Bryozoa (among them Zoobotryon pellucidum) and Ascidians were found in the harbour of Rhodes city and its neighbourhoods. Actinia equina seems to be missing, but on the opposite shores of Anatolia a good number of fine specimens were found. In shallow water during summer Aplysia was plentiful and grazing among seaweeds; a good series of other Mollusca were collected, too. Among other species were Tethys leporina and two different Octopus. Colonies of Pyrosoma and some Hydromedusæ were the only pelagic animals that could be obtained. Twenty species of Echinoderms were gathered : among them Tethyaster, Ceramaster and Centrostephanus were quite common in rather deep water, more or less distant from the shore. Crustaceans were fairly abundant, and among the largest Malacostraca Squilla mantis, Scyllarides latus, Maia squinado, Calappa granulata and Dromia vulgaris do not appear to have been previously noticed, as well as Pagurus striatus, a common dweller of large shells of Cassis sulcosa and Murex trunculus.

Fishes were particularly looked for, and collected species amounted to 116 , of which six were Plagiostomia. Fishermen are few, and their work even in normal times is not a profitable one. The cause is to be found both in scarcity of plankton, that does not foster a rich fish-life, and in the nature of the seabottom, that forbids using some fishing technique otherwise advantageous. Ambiental conditions are unfavourable to fishes the life of which is largely dependent on development of continental shelf, as are Heterosomata, of which four species only were obtained. Shoals of migratory fishes (Scombroids, etc.) coming from the Black Sea or going there appear near Rhodes, but cannot support fisheries on an industrial scale. As a whole, these animals are much more numerous along the coasts of Asia Minor. Large sea-basses, mullets, red mullets, hakes and some sparoids were most frequently observed to be sold. This fish fauna shows a rather tropical character, that is stressed not only by such chiefly tropical families as Labroids and Carangoids or genera such as Sardinella and Sparisoma, but also by the presence of Red Sea immigrants. Only one of these, Siganus rivulatus, had previously been found in Aegean waters. Two other species may now be added-Hemirhamphus marginatus and Monacanthus setifer, the latter hitherto found only in Palestine. Apart from some species such as the small ray (Raia radula), that are more or less localized and the recognition of which is therefore interesting, four species, of which a single specimen was found in Rhodes, deserve particular mention. Lobotes surinamensis, a percoid, and Remilegia australis, a remora (sucking-fish), are tropical species of which we had but one Mediterranean record: the former was captured in Palermo (1875), the latter in Trieste (1881). Scyris alexandrinus, a form of deep-bodied carangoid, seems to be rare and until now was reporced only from North Africa and Syria. Gobius thori is a little goby of which only the type specimen, collected by the Thor near Tenedo (northern Aegean Sea) many years ago, was known.

All this material was unfortunately lost, but all notes and drawings were fortunately preserved, so that it has been possible to deal with it particularly in separate papers, that will appear-it is hopedas soon as printing difficulties will allow.

\section{RADIOCHEMISTRY IN BRITAIN}

\section{OPENING OF THE LONDONDERRY LABORATORY AT DURHAM}

$G^{R}$ REAT BRITAIN was in the forefront of original research on the chemistry of the radio-elements so long as Frederick Soddy, after his return from Montreal, was devoting his activities to this field. Much of the experimental material which led to his conception of isotopy was collected in his laboratories in Glasgow by A. Fleck; the first thorium-lead was prepared there and its atomic weight determined; and protoactinium was discovered by Soddy and Cranston in Aberdeen simultaneously with Hahn and Meitner in Berlin-Dahlem. No chemical laboratory in Great Britain, however, has followed up the tradition, so that from about 1918 on, the centres of radiochemical research were the Laboratoire Curie in Paris, and the Radium Department of the Kaiser Wilhelm Institut für Chemie at Dahlem, under Otto Hahn. How important their work was may be seen from the one fact that the discovery of the fission of uranium was an achievement to which the systematic study of the chemical products of the uranium irradiation was bound to lead, and to which the Paris laboratory had already come very close when Hahn and Strassmann's fundamental paper appeared. In Britain no corresponding work was undertaken, in spite of several physicists being greatly interested in the problem.

The need for a revival of radiochemistry was keenly felt during the Second World War, when the military and economic possibilities of the use of atomic energy had been recognized, and in Montreal a joint British--Canadian Government team, first under the directorship of Dr. H. Halban, and later under that of Prof. J. D. Cockeroft, did research work on uranium fission. The chemistry division of that team, built up during the years 1943-45 under Prof. F. A. Paneth, comprised finally more than thirty graduates, many of whom had been recruited in Britain.

It would have been deplorable if at the end of the War still no British university had shown interest in the study of radiochemistry. Fortunately, the University of Durham, with the support of the University Grants Committee, found ways and means of building a laboratory in which radiochemical specialists can carry out their researches and, at the same time, train young chemists in the particular techniques which will enable them to collaborate with the departments of nuclear physics in universities and Government establishments, and also with 